\title{
スウェーデンにおける地理学教育
}

\author{
村 山朝 子* 村山祐 司**
}

\section{Geography Education in Sweden}

\author{
Tomoko MURAYAMA* and Yuji MURAYAMA**
}

\section{I. はじめに一スウェーデンの大学の性格}

スウェーデンの大学における地理学教育につい て理解しようとするならば, その基盤となる大学 の性格について知るのが先決であろう。それによっ て, おのずと大学における地理学教育の特質, 日 本との相違点も浮かび上がってくるに違いない。

教育と研究はともに大学の機能である。教育の 点からいえば, 学生にとって大学は到達点ではな く，社会における通過点にすぎない。日本でも同 じことであるのかもしれないが，スウェーデンで はとくにその傾向が強い。大学は社会の中にあり, 労働市場と密接な関わりをもつ。教育と就労, 大 学と社会は双方向性を有している。中等教育終了 後, 高等教育にそのまま進学する者はこれまで 3 分の 1 程度で推移してきたが，このなかには多種 多様な高等教育機関が含まれており，大学進学者 に限ればそれほど高くない。学部学生の年歯構成 をみると, 従来は 25 歳以上に対して就労経験を 勘案する特別入学枠が設けられていたこともあっ て，学生の多くがいわゆる社会人入学であった。 いったん社会に出て労働経験をもったうえで大学 に戻るのが，スウェーデンではごくあたりまえの ことである1)。

大学のもう一つの機能である研究についていえ ば，スウェーデンにおいては，実質上国内のあら ゆる研究活動は教育現場との密接な協力に基盤を おいている。公共部門に限らず民間部門も含めて,
研究・開発は学部教育や大学院教育など大学との 連携が図られている。例えば自動車メーカーとし て世界的に有名なボルボは, 新車開発でシャルマー ル工科大学と共同研究を行ない, また, イエテボ リ大学の時間地理学者に生産体制のソフト面の改 善の研究を委託している。

このように, 大学が教育・研究の両面で社会と 緊密な結びっきをもっていることがスウェーデン の大学の最大の特色としてあげられる。目下， 21 世紀に向けての大規模な教育改革が進行中である が, この特色は今後も引き継がれるであろう（Ministry of Education and Science, 1994)。地理学 も常に社会との密接な関わりに扔いて発展し, そ うした環境のもとで地理学教育は行なわれてきた のであり，その点も扔そらく変わらないであろう。 筆者は1994年から1995年にかけて, スウェーデ ンの 3 つの大学の人文系地理学科に扔いて調査・ 研究に従事した。その経験をふまえて, 本稿はス ウェーデンの大学の人文系地理学科に扔ける地理 学教育について述べることとする。

\section{II. 地理学の動向}

大学に扩ける地理学教育は, その国の地理学の 動向と表裏一体にある。計量地理学, 時間地理学, コンピュータマッピング2), いずれもスウェーデ ンに端を発する比較的歴史の新しい地理学の分野 である。こうした分野が生まれた背景には社会の ニーズがあり, それが地理学発展の原動力となっ

* 茨城大学教育学部 (非)

** 筑波大学地球科学系

* Faculty of Education, Ibaraki University

** Institute of Geoscience, University of Tsukuba 
てきたといえよう。スウェーデンの地理学は問題 指向 (problem-oriented) であり，スウェーデン 社会の変化や政策の流れを把握せずに, 地理学の 動向を語ることはできない。研究のテーマや関心 はもちろんのこと, 生み出された理論や開発され た手法も, そのときどきの社会状況や政策と密接 に関連している。一例を挙げれば, 時間地理学が 発展したことは, 個性を尊重し公平な生活者社会 の実現をめざした社会民主党の長期政策と決して 無縁ではない。

スウェーデンの地理学者は学際的な研究会合に 頻繁に参加し, 他の分野の研究者と積極的に共同 研究を組織する。他分野の研究成果に絶えず目を 配り，有効な方法論であれば積極的に取り入れる。 研究課題の達成が重要なのであって, 研究スタイ ルや方法論が地理学であるかどうかはたいした問 題ではないと彼らは考えているようにも見える。

人文地理学についていえば, 昨今は分布や地域 差に着目するマクロな研究よりも, 小地域を対象 とした非集計レベルの研究（生のデータを重視す る）が盛んである。地方分権政策の浸透や生活者 社会の成熟を背景に, この傾向はますます強まっ ていくように思われる。

地理学教育はこうした地理学の動向を受けて, 多様なカリキュラムを組んで行なわれる。

\section{III. 大学における地理学教育体制}

\section{1) 学科構成}

地理学科はスウェーデンにある $6 つ の$ 総合大学 にはもれなくおかれている3)。そのうち 4 大学は 自然地理学科と人文地理学系の学科を併設するが, 両学科はそれぞれ独立した別組織となっている。 自然地理学科に在籍する学生は, その他の自然科 学分野を選択することはあっても, 人文地理学に ついては必修とは限らない。一方, 人文地理学科 の学生の多くは経済学や社会学を選択するが, 自 然地理学は必修ではない。スタッフのレベルでの 相互交流にいたっては, 少なくとも1980 年代ま では極めて希薄であった。

自然地理学科には通常, 地形学, 気候学, 水文 学が含まれ, リモートセンシングや GIS も盛んで
ある。学科名はいずれの大学も「自然地理学科」 に統一されている。一方, 人文地理系の学科につ いては, 大学によって学科名も所属学部もさまざ まである。例えばイエテボリ大学では, 人文・経 済地理学科の名で経済・商法学部に属する。ルン ド大学とウプサラ大学は, 社会・経済地理学科, 人文のみを冠するのはストックホルム大学の人文 地理学科だけである。学科名が異なるように, 各 教室はそれぞれ独自の研究カラーをもっている4)。

\section{2) 教育体制}

学科のスタッフは, 研究を主とする教授, 研究 と教育の両方に関わる主任講師 (högskolelektor), 学部での教育指導が主となる講師 (högskoleadjunkt）の 3 職からなる。地理学科は, 総合 大学では $1 \sim 3$ 名の教授と $10 \sim 20$ 名前後の主任講 師・講師から構成される。学部教育を支えている のは多くの主任講師ならびに講師たちであるが, 学部教育指導で示された講義力が教授任命の際の 判断基準となることが近年の大学改革で新たに加 えられ，大学における教育機能がこれまで以上に 重視されるようになったことが注目される。そう はいっても, 講師陣の多くは期限付きの不安定な 立場で日々の学部の授業に追われるのが現状であ る。彼らの多くは政府や民間の委託研究プロジェ クトに参加して研究費を得ている。その一方で非 常勤講師の中には, 例えば本業の経営コンサル夕 ントの傍ら大学で GIS を教えるというように, 主 たる仕事場を他にもち, 大学で 1,2 の授業を担 当する者もいる。また, コミュニティの運営スタッ フの一員として活動したり, 議員として政治に関 わる教授もいる。このように, 大学の地理学スタッ フの多くは, 社会とのつながりをもちながら地理 学研究や教育に携わっている。

\section{3）学生の動向}

地理学志望の学生は近年増加傾向にある。それ は後述のように, 1990 年代に入って高校における 教科地理の復活にともない地理教員の需要が新た に生じたことが最大の要因ではあろうが, 環境問 題をはじめとする現代社会の諸問題への自然と人 文・社会の両面からのアプローチに対する社会的 要請と, それに対する学生の関心の高まりも見逃 
せない。

大学院については, 学部卒業後直ちに進学し短 期間で学位取得をめざすよりもむしろ学位取得の ために休職して大学院に在籍するか, 仕事を続け ながら長期戦で論文を作成するほうが一般的であ る。院生は原則として奨学金を得ているが, 委託 研究プロジェクトに加わって資金を得る者も少な くない。補佐や非常勤講師として学部レベルの教 育に関わる場合もある。学位を取得する年齢は平 均すると 30 代半ば過ぎであろう。

\section{IV. 地理学科の教育課程}

スウェーデンの大学のカリキュラムは日本に比 べてはるかに自由度が高い ${ }^{5)}$ 。学部の修業年限に も 2 年から 5 年半と幅がある。 1 学年度は 2 期 40 週からなる。履修はポイント制がとられ， 1 週フ ルタイムで 1 ポイント，1学期間のフルタイムに よる履修は20ポイントとなる。1991 年の改革以降, 大学のカリキュラム編成権が拡大され, また学生 の選択の幅も広がり, 異なる専攻の専門科目を組 み合わせて学位を取得することも可能となった。 80ポイントで卒業（ディプロマ），120 ポイント (うち 60 ポイントは同一専攻科目) で学士, 160 ポイント（うち 80 ポイントは同一専攻科目）で 修士の資格が得られる。なお，大学院に関しては 通常 4 年制の博士課程が総合大学抢よび一部の専 門大学に設置されている。国際的競争力を高める ために，近年大学院教育の拡充が図られている。

カリキュラムは大学・学科によって独自のもの が作成されている。通常，メジャーコースとして， 卒業に必要な 80 ポイントをとれるコースがいく つか設置され，そのほかマイナーコースとして 5〜10 ポイントの単独科目が複数設けられている。 メジャーコースに打ける各コースは通常, 基礎コー ス 40 ポイント, 中級コース 20 ポイント, 上級コー ス 20 ポイントからなり，それぞれ複数の科目か ら構成され，3４名の講師により行なわれている。 例えば, イエテボリ大学人文・経済地理学科の場 合, 地理学, 人文地理学, 経済地理学の 3 コース が設定されている。このうち地理学コースは自然 地理学科との共同で行なわれている ${ }^{6)}$ 。
学生はメジャーコースのほかマイナーコースの 単独科目を各自が自由に組み合わせて履修する。 単独科目の内容は大学によってさまざまで, 独自 色が強い。例えば, ルンド大学社会・経済地理学 科では20ポイントの第三世界研究コースが 2 つ設 けられているほか, 景観・集落・人間, 社会地理 学入門, 社会地理学, 地域開発計画, 経済活動の グローバリゼーション, 経済地理学入門, 企業と 社会, 社会地理学と計画などの単独科目（各 10 ポイント）がある。また，イエテボリ大学の人文・ 経済地理学科のスタッフは経済・商法学部の一般 科目である商業経営と経済, 国際ビジネス経営と 経済, サービスマネジメント, 交通経済と物流, 自治体行政なども受けもっている。ストックホル 厶大学人文地理学科では, 経済学, 統計学, 社会 学, 環境計画, 民族学などのスタッフとともに, 都市および地方計画基礎コースという 140 ポイン トの総合コースを構成している。

このように, カリキュラムは各学科が所属する 学部のカラーと学科スタッフの研究領域を反映し, それぞれ特色あるものになっている。

\section{V. 大学の地理学教育と学校地理との関わり}

わが国の大学における地理学教室の存在は, 小 . 中・高における地理および社会科教員養成に依拠 してきたところが大であることは否定できない。 スウェーデンでは大学における教員養成の中心は 高校教員養成であるが，地理学教育は 1970,80 年代には実質的に学校教員養成の機能をもってい なかった。というのは1960 年代後半に高校の教 科教育から地理がはずされたために，地理学科で 地理教員を養成することは実質的になくなったの である ${ }^{7)}$ 。1990 年代に入って教科地理が復活する までの四半世紀余りの地理教員養成課程の空白は, 結果的に地理学の専門化に拍車をかけることにな り, 地理学は社会科学として, あるいは自然科学 として個別科学の傾向を一層強め, 各分野は個々 に発展を遂げていった。その一方で, 地理の教 育的機能ともいうべき総合力や自然と人文の関わ りの視点の欠落を招く結果となった。

大学における地理学の研究対象について高校生 
はどのように考えているかについて1980 年代末に 調查が行なわれた。調査結果では半数が地名や地 図と答えており, 現実の地理学研究との間には大 きな隔たりがみられる ${ }^{8)}$ 。スウェーデンの地理学 が世界に名をとどろかせたという意味での最盛期 は 1950, 60 年代であり, その後のスウェーデン の地理学の地位は相対的に低迷していることは否 めない。1970, 80 年代の高校における教科地理の 空白は, 地理を中学までの学校地理のイメージに 固定化し, 結果的に大学における人材不足, 地理 学研究の停滞を招く一因となったのではないだろ うか。しかし, 学校教育の教科目に名のない学問 分野でも優れた研究者を輩出し, 学問として発展 を見せている分野は少なくない。逆にいえば, 教 科教育により固定化された地理のイメージが地理 学の発展の妨げになっているのかもしれない。と はいえ 1990 年代に入ってからの高校における教 科地理の復活は, 逆に大学の地理学教育の活性化 に一役買っているのも事実である。新たに加わっ た教員養成機能は, 大学の地理学教育の性格にも 今後は少なからず影響を与えていくことであろう。

\section{VI. おわりに一地理学教育のこれから一}

スウェーデンについて何かを語る場合には，そ れがいつのことであるのかを明示しなければなら ない。実験国家とも称されるように, 絶えざる改 革のもと社会は常に変化しているからである。教 育もその例外ではない。1990 年代, スウェーデン の教育界は高等教育も含めて変革の渦中にあり, 地理学教育についてみていくのにも, そのことに 留意する必要がある。

これまで専門教育に重点をおいてきた大学の中 で, 地理学教育は研究者ばかりでなく多数の実務 のスペシャリストを世に送り出してきた。1991年 の改革以降, 学生は自由に自らコースを組み立て 単位取得ができるようになり, 大学教育の性格が 少しずつ変化し始めている。学部教育は質の維持 を図りながらも大衆化の方向にもあり, 一方, 大 学院教育は国際競争力の強化の原動力となるべく 一層の充実が急がれている。地理学教育は, 大学 院教育を中心に教育の質を高めてこれまでにも増
して有能なスペシャリストを養成する一方で, 学 部教育の自由なコース選択の中で, 広く教養とし ての地理学としての役割も今後は求められてくる のではないかと予想される。また, 自然地理学科 と人文系地理学科はこれまで別個の組織としてス タッフも学生も交流は少なかったが, 教員養成課 程の新設を機に両学科による合同コースも拡充さ れ, 教員志望者以外でも一方の学科学生が他方の 講義をとるケースも増えてきているようである。 専門化を押し進めてきた地理学にも摇り戻し的現 象がみられる。

21 世紀のスウェーデンの地理学のビジョンはま だ明確には見えてこないが, 常に社会の要請を敏 感に捉えて新しい視点と手法を提示してきたその 姿勢は今後も変わらないであろう。

それにしても，21世紀の社会が求めているのは， 地理学が本質的に有しているであろう総合力であ るのかもしれない。近年のスウェーデンの地理学 教育の動向がそれを予感させる。

\section{注}

1）ただし1990年代に入って状況は変化している。社会 人枠が撤廃され，また労働市場の停滞も手伝って若年 層が増加している。

2) 村山祐司 (1996) p. 417参照.

3) 総合大学のルンド, イエテボリ, ストックホルム, ウプサラ, ウメオ, リンチョピング, そして単科大学 のストックホルム商科大に扔かれている. また単科大 学のカールスタッド, エルブロ, ベクショーにも教員 養成を主体とした地理学科がおかれる. 自然と人文両 学科が並存するのはルンド, イエテボリ, ストックホ ルム, ウプサラの 4 大学である.

4) 人文地理学教員 118 名の関心分野についての調査結 果によれば, イエボリ大学の交通地理, ストックホル 厶大学の歴史地理, ウメオ大学の都市・地域計画など 大学毎のカラーがでている.この調査結果からスウェー デンの人文地理学の状況を読むこともできよう. 総じ て系統地理学的アプローチに傾斜し, なかでも経済地 理, 立地論, 社会地理, 都市計画など社会科学分野に 対する関心が高く，それに比べて地誌学や地理教育へ の関心は低い.

5）1989 年までは一般教育について国がカリキュラム を作成していたが，それも廃止された。

6）イエテボリ大学人文経済地理学科 1994/95 年の地理 学コースの基礎コース40ポイント (p) の内訳は以下 の通り. (1)コースの概要と地図学 2 p. (2)自然地理学: 地形学々気候学 $6 \mathrm{p}$. (3)人文地理学: 経済地理学 $6 \mathrm{p}$. (4)地域地理学 $6 \mathrm{p}$. (5)土壤. 気象・水文 $5 \mathrm{p}$. (6)開発 
地理学 5 p. (7)環境 4 p. (8)自主研究 6 p.

7） 1960 年代後半に総合教科としての社会科と理科が 新設され，従来の教科地理の人文地理的内容は社会科 に, 自然地理的内容は理科に吸収され, 独立教科とし ての地理は姿を消した。1990 年代に入って再び両者 は統合されて教科地理は復活した。詳細は村山朝子 (1995) 参照.

8) Holmén et al. (1993) によれば，回答者 185 名 中，地名/地図と答えたのが 92 名，未知の地域につ いて 63 名, 自然地理 25 名, 世界の見方 18 名, 地域 区分 15 名, 気候 11 名, 人口移動 7 名, その他 7 名.

\section{文献}

村山朝子 (1995): スウェーデンにみる地理教育の再生 一高校における教科地理の復活一。人文地理，47-6, 65-79.

村山朝子 (1996): スウェーデンにおける地理教育の構 造と理念一新しい教科地理は何をめざすのか一. 新地 理, 44-1, 1-14.

村山祐司 (1996): スウェーデンにおける人文地理学の 展開. 地学雑誌, 105，411-430.

Holmén, H. et al. (1993): Geografiämnet I Gymnasiet. Lunds Universitet, 208p.

Ministry of Education and Science (1994): Strategies for Education and Research 1994. $30 \mathrm{p}$. 